\title{
Restoration that targets function as opposed to structure: replacing lost bivalve production and filtration
}

\author{
Deborah P. French McCay ${ }^{1, *}$, Charles H. Peterson ${ }^{2}$, \\ Joseph T. DeAlteris, ${ }^{3}$ John Catena ${ }^{4}$ \\ ${ }^{1}$ Applied Science Associates, 70 Dean Knauss Drive, Narragansett, Rhode Island 02882, USA \\ ${ }^{2}$ Institute of Marine Sciences, University of North Carolina at Chapel Hill, Morehead City, North Carolina 28557, USA \\ ${ }^{3}$ University of Rhode Island, Building 50, East Farm, Kingston, Rhode Island 02881, USA \\ ${ }^{4}$ National Oceanic and Atmospheric Administration, National Marine Fisheries Service, Restoration Center, \\ 1 Blackburn Drive, Gloucester, Massachusetts 01930, USA
}

\begin{abstract}
Abundant suspension-feeding bivalves have a dominant organizing role in shallow aquatic systems by filtering overlying waters, affecting biogeochemical processing, and diverting production from the water column to the benthos. In degraded aquatic systems where bivalve populations have been reduced, successful restoration of ecosystem functions may be achieved by targeting the revival of bivalve populations. The 'North Cape' oil spill on the coast of Rhode Island (USA) provides an opportunity to demonstrate the feasibility of scaling bivalve restoration to meet quantitative goals of enhanced production. After this oil spill, mortalities of bivalves were estimated by impact assessment modeling of acute toxicity, and results were confirmed by comparisons with counts of dead and moribund animals on local beaches. Computation of lost bivalve production included future production expected from affected animals, had they lived out their expected life spans. This calculation of production forgone required a demographic model that combined age-specific mortality with individual growth. Application of this modeling approach to surf clams Spisula solidissima, the species that comprised $97 \%$ of the total loss of bivalve production from the spill, illustrates the detailed implementation of scaling restoration to match estimates of losses. We consider the factors known to limit abundance and production of surf clams and other marine bivalves (hard clams, American oysters and bay scallops) and review the advantages of hatchery stocking, transplantation, habitat restoration, and reduction of fishing pressure in selecting a reliable and efficient restoration action. Age-specific estimates of the scale of population enhancement required to restore production showed that fewer additional animals were needed when larger (older) animals were added, but at the expense of greater grow-out requirements. Relaxation of fishing was most effective for hard clams. Accurate scaling of restoration was most sensitive to mortality rate, and the most efficient restoration involving seeding of small bivalves would be accomplished using surf clams. Monitoring of the restoration option chosen to compensate for the bivalve loss following the 'North Cape' oil spill can serve to test the underlying demographic assumptions and accuracy of the restoration scaling.
\end{abstract}

KEY WORDS: Bivalves · Loss · Limiting factors · Natural resource damage assessment · 'North Cape' oil spill $\cdot$ Population modeling $\cdot$ Restoration

Resale or republication not permitted without written consent of the publisher

\section{INTRODUCTION}

Restoration ecology has focussed mostly on replenishing species that provide physical structure to the habitat, typically the larger plants (Jordan et al. 1987).
In the marine environment, this approach explains the overwhelming dominance of restoration projects and studies that are devoted to salt marsh grasses and seagrasses (Thayer 1992). The restoration of structure has compelling justification in that the function and value 
of a habitat are usually determined by its structural integrity (e.g. Wilson \& Peters 1988) and the defining structure of many marine habitats is provided by the larger plants and reef-building animals. Nevertheless, provision of habitat structure does not necessarily guarantee the return of normal function and the rate of return of function may often lag structural restoration by many years (Zedler 1995, Fonseca et al. 1996, 1998). Consequently, the field of restoration ecology could benefit and grow from greater appreciation of the functional organization of the biological communities within ecosystems and from targeting some restoration efforts directly towards re-establishment of the limited number of functionally significant species that are the strong interactors in the system (Paine 1980).

Within estuaries and other relatively shallow aquatic ecosystems, suspension-feeding bivalve molluscs can dictate the character of the entire system through their water filtration function (Kremer \& Nixon 1978, Cloern 1982). The significance of bivalves in clarifying the waters, in driving energy flows from pelagic to benthic food chains, and in promoting growth of light-limited benthic macrophytes, which themselves serve as critical habitat, can be clearly displayed through observing the consequences of unplanned perturbations of bivalve populations. The ecosystem consequences of zebra mussel Dreissena polymorpha invasions in the Great Lakes and the introduction of the Asian clams Potamocorbula amurensis to San Francisco Bay have resulted in dramatic changes in the aquatic ecosystem, consistent with their functional roles as filters (Nichols et al. 1990, MacIsaac et al. 1999). Where natural bivalve populations have been reduced (e.g. oysters in the Chesapeake Bay and other estuaries) turbidity of estuarine waters has increased, promoting pelagic jellyfish explosions, and leading to widespread seagrass loss (Newell 1988, Jackson et al. 2001). This ecosystem service of water filtration serves as a topdown grazing control on algal blooms, perhaps the most serious direct symptom of eutrophication, one that leads indirectly to oxygen depletion and mass mortalities of invertebrates and fish. Bivalve filtration also counteracts eutrophication by inducing higher rates of denitrification (Newell et al. 2002).

In addition to their ecosystem role as biological filters, harvested populations of bivalves are a source of food and recreation for humans. The over-exploitation of abundant estuarine bivalves is in large measure responsible for their decline in estuaries and for recent collapses of estuarine ecosystems (Jackson et al. 2001). However, because of their economic value, there also is a wealth of information about bivalve population dynamics and technologies developed to sustain and enhance stocks. All of this is useful in restoring depleted populations and here we consider potential opportunities for estuarine restoration through enhancing suspension-feeding bivalves and thus their filtration function in the system. As an example, we use a restoration assessment performed to replace the loss of ecosystem services of surf clams and other bivalve molluscs following the 'North Cape' oil spill in Rhode Island, USA, and develop a quantitative demographic model for growth, survival, and production of surf clams. When coupled with estimates of clam density, the model allows quantitative estimation of surf clam biomass-production lost after the spill. We then illustrate by application of analogous demographic models of bivalve production how a bivalve enhancement project can be quantitatively scaled to compensate for the loss in ecosystem services caused by loss of surf clams and other bivalves after exposure to oil or other pollutants.

\section{MATERIALS AND METHODS}

Loss of production by bivalves. After the barge 'North Cape' grounded on the south coast of Rhode Island (USA) during a severe winter storm on 19 January 1996, most of the 2682 metric tons (828 000 gallons or $3130 \mathrm{~m}^{3}$ ) of No. 2 fuel oil that was spilled became rapidly entrained into the water column by the heavy surf (French McCay 2003). This mixing process resulted in high concentrations of polynuclear aromatic hydrocarbons (PAHs) throughout the water column, sufficient to induce mass mortality of benthic marine animals suffering from narcosis. The induction of acute toxicity became evident as numerous lobsters $\mathrm{Ho}$ marus americanus, surf clams Spisula solidissima, blue mussels Mytilus edulis, rock crabs Cancer spp., seastars, ampeliscid amphipods, hard clams Mercenaria mercenaria, and demersal fishes washed up dead or moribund on beaches for several days beginning immediately after the spill (Gibson 1997). These dead animals had occupied either the sand-bottom or the cobble-boulder habitats in the shallow subtidal shelf contiguous with the beach. Oil was also transported into coastal lagoons (termed salt ponds), where additional losses of benthic invertebrates such as soft-shell clams Mya arenaria, eastern oysters Crassostrea virginica, and bay scallops Argopecten irradians followed (French \& Rines 1998).

Losses of bivalve molluscs were quantified by integrating several studies. Field sampling was conducted on 2 dates after the oil spill to quantify local post-spill abundance of surf clams by size (age) class in and out of the spill-affected zone. Physical fates modeling was used to predict water column PAH concentrations, which were validated with observed PAH concentrations in the water column at multiple locations. Based on known acute toxicity levels for appropriate taxa and 
estimates of pre-spill abundances, an ecotoxicological impact assessment model was employed to estimate mortalities of species, including surf clams and other bivalves, in the marine and salt pond environments. The estimated surf clam mortality was compared to the estimated number stranded on beaches near the impact site after the spill. We converted the loss of surf clams to an estimated loss of biomass from size frequency distributions of killed clams and the applicable size-weight relationship. Finally, we developed a demographic model of surf clam individual growth and mortality to compute the production forgone because of the additional lifetime growth that would have been expected had those dead animals survived to complete their natural expected life spans. The biomass of the immediate kill and the production forgone were combined to yield the total loss of production caused by the oil spill.

Minimum estimate of surf clam mortality. Sampling of stranded surf clams was conducted daily at low tide from 20 to 22 January 1996 on 6 impacted beaches (Fig. 1). Two control beaches west (Westerly) and east (Newport) of the impact zone were sampled to quantify purely storm-induced strandings (Gibson 1997). On each impacted beach, $2 \times 200 \mathrm{~m}$-long transects were established parallel to the shore at low tide, from which dispersed sets of randomly placed quadrats were used to quantify densities and size frequency distributions of bivalves. The total area covered by strandings was also estimated on each affected beach. Since logistics precluded sweeping the transects clear of stranded animals, the overall mean density $(3.65, \mathrm{SE}=1.08)$ for the $3 \mathrm{~d}$ of sampling, less the mean $(0.04, \mathrm{SE}=0.03)$ for the control beaches, was multiplied by mean width $(5.73 \mathrm{~m}$, $\mathrm{SE}=0.77)$ and length $(15955 \mathrm{~m})$ of the impacted beach to estimate a minimum number of 330300 surf clams stranded on the shoreline (Gibson 1997). Although more surf clams came ashore on subsequent days, they were not counted. Gibson (1997) estimated total surf clam strandings at 1.8 million. This estimate does not represent total surf clam mortality because not all clams killed became stranded on the beaches. Specifically, smaller clams were absent from the strandings: no clam $<3.6 \mathrm{~cm}$ in length, and few $<7 \mathrm{~cm}$, were observed on the beaches. A $3.6 \mathrm{~cm}$ surf clam would be in its second year of life (Weissberger 1998), meaning that none of the young-of-the-year (YOY; and few 1 yr-olds) were included in the strandings. Thus, the estimated number of surf clams stranded represents the minimum loss of clams $>1+$ yr of age.

Density of surf clams. Surf clams were sampled in and out of the spill-affected area, providing density data for input to the ecotoxicological impact assessment model and improving estimation of production forgone by providing site-specific growth and survivorship information. In May/June 1997, 17 mo after the oil spill, surf clams were sampled using 2 different sampling devices along 1 transect in the impacted (W) and 1 in the adjacent control area (FW) to the west (Fig. 1). Each transect contained 5 stations and was oriented perpendicular to shore, extending out to a depth of $10 \mathrm{~m}$, the limit found to be minimally impacted in the ecotoxicological model. One sampler was an $8.4 \mathrm{~cm}$ diameter core sieved through a $2 \mathrm{~mm}$ mesh; the other was a suction dredge that passed contents of a $1 \mathrm{~m}^{2}$

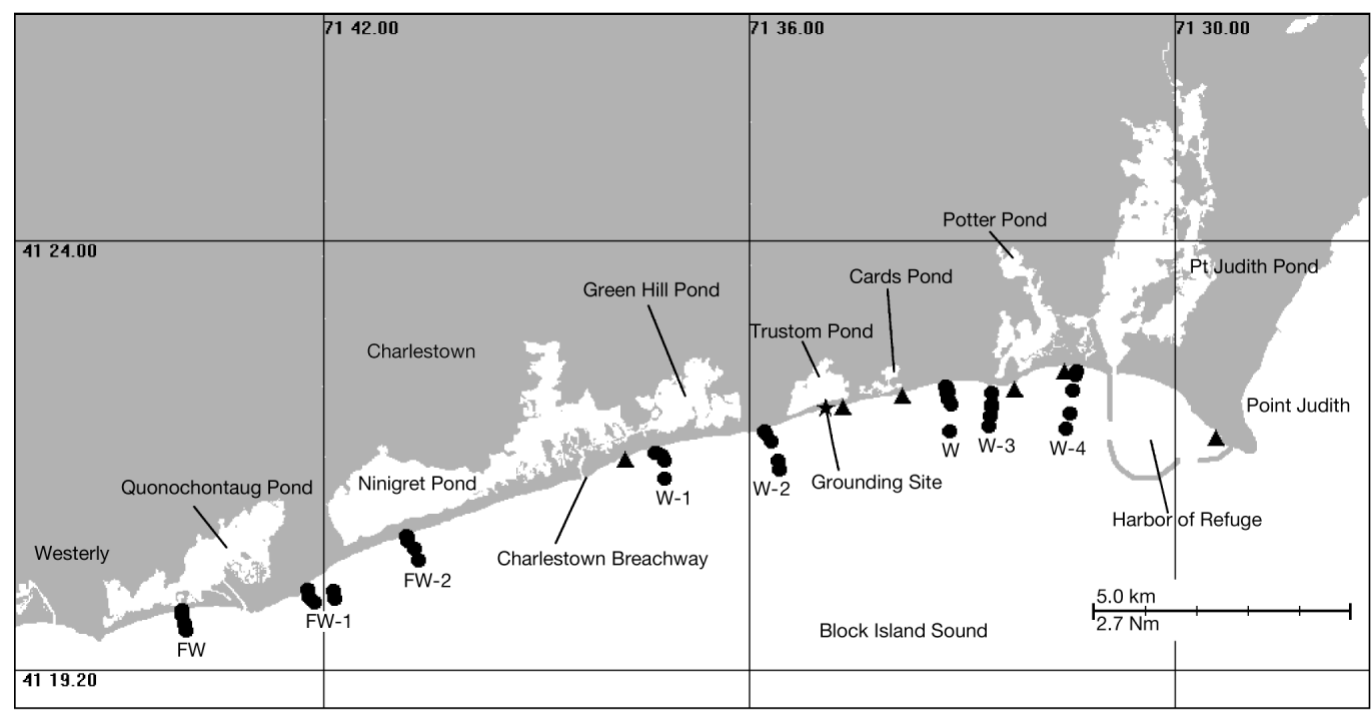

Fig. 1. Transect locations on the south coast of Rhode Island (USA) for sampling surf clams Spisula solidissima: (1) stranded on beaches (triangles), conducted daily at low tide 20 to 22 January 1996; and (2) densities in subtidal sediments (circles), taken by core and dredge in May/June 1997 and December 1997 to February 1998. The 'North Cape' grounding site is indicated by the star. The impact zone extended along the shore to $10 \mathrm{~m}$ deep water (i.e. at the outer station of each W transect) from Point Judith to the Charlestown Breachway. W: impacted sites; FW: adjacent control areas 
sample frame through a mesh bag with $4 \times 6 \mathrm{~mm}$ openings. These 2 sampling devices produce largely complementary information, in that the dredge sample did not fully retain YOY clams, whereas the core could not capture larger clams approaching the diameter of the tube. At each station, 30 core and 15 dredge samples were randomly placed and collected clams were counted and measured (shell length; Tables 1 \& 2).

Surf clams were sampled a second time from December 1997 to February 1998, 24 mo after the spill, using only the dredge sampler at 3 original stations and 30 new stations (Fig. 1, Table 2). Because the dredge sampler missed the smallest YOY clams, we used a correction factor for that undercounting to render the December 1997 to February 1998 density estimates for YOY comparable with previous densities estimated by coring. In the May/June 1997 samplings along the FW transect, the ratio of YOY density in cores (Table 1) to that in dredge samples (Table 2) was 17.0 ( $\mathrm{SD}=14.7$ ). For the period of December 1997 to February 1998, YOY density was estimated as $17.0 \times$ the measured dredge-sample density (in Table 2) to correct for the under-sampling of those size clams. Clams were found in fine to course sand, but not at locations where granules or rock boulders were present.

Surf clam recruitment response after the oil spill. The surf clam samples provide some insight into the likely loss of clams from the oil spill and into the population dynamics of surf clams. Dredge sampling 17 mo after the spill uncovered no surf clams large enough to have been present before the spill ( $>3.6 \mathrm{~cm}$ length) in the impact area and only $1 \mathrm{clam}(15.1 \mathrm{~cm}$ long) in the control area (Table 2). Thus, this information is consistent with the assumption of mass mortality of surf clams in the spill area (1 to $40 \%$ mortality was computed by and applied in the biological effects model, French McCay 2003). Nevertheless, the similarly low density of older surf clams in the presumptive control area to the west raises questions. The core sampling in

Table 1. Mean grain size ( $\mathrm{mm}$ ) and density (ind. $\mathrm{m}^{-2}$ ) of surf clams Spisula solidissima along impacted (W) and control (FW) transects (see Fig. 1), based on $8.4 \mathrm{~cm}$-diameter core samples (30 replicates per station) taken in the spring of 1997

\begin{tabular}{|lcccc|}
\hline Transect & $\begin{array}{c}\text { Depth } \\
(\mathrm{m})\end{array}$ & $\begin{array}{c}\text { Date sampled } \\
\text { (dd/mm/yy) }\end{array}$ & $\begin{array}{c}\text { Grain } \\
\text { size }(\mathrm{mm})\end{array}$ & $\begin{array}{c}\text { Density } \\
\text { Mean (SD) }\end{array}$ \\
\hline $\mathrm{W}$ & 3 & $19 / 05 / 97$ & 0.1 & $763.9(438.7)$ \\
$\mathrm{W}$ & 4 & $18 / 05 / 97$ & 0.1 & $926.3(539.8)$ \\
$\mathrm{W}$ & 6 & $18 / 05 / 97$ & 0.1 & $324.8(352.7)$ \\
$\mathrm{W}$ & 8 & $19 / 05 / 97$ & 1.1 & $0(0)$ \\
$\mathrm{W}$ & 10 & $20 / 05 / 97$ & 2.1 & $0(0)$ \\
FW & 3 & $24 / 05 / 97$ & 0.3 & $6.0(33.0)$ \\
FW & 4 & $24 / 05 / 97$ & 0.2 & $30.1(68.4)$ \\
FW & 6 & $25 / 05 / 97$ & 0.1 & $18.1(55.1)$ \\
FW & 8 & $27 / 05 / 97$ & 0.1 & $0(0)$ \\
FW & 10 & $27 / 05 / 97$ & 0.1 & $6.0(33.0)$ \\
\hline
\end{tabular}

May/June 1997 revealed numerous surf clams of 1.4 to $1.9 \mathrm{~cm}$ in length in the control area (mean $=12.0 \mathrm{~m}^{-2}$; $\mathrm{SD}=7.0 \mathrm{~m}^{-2}$ ) but far more on the impacted transect at stations with sand $\left(\right.$ mean $\left.=672 \mathrm{~m}^{-2} ; \mathrm{SD}=311 \mathrm{~m}^{-2}\right)$, but not granular $(>1 \mathrm{~mm})$ sediments (Table 1$)$. This size class presumably reflects animals of ca. $1 \mathrm{yr}$ of age (Weissberger 1998). Consequently, these clams had settled in the first summer (1996) after the oil spill. Based on dredge sampling for both sampling periods, and the correction factor 17.0 for under-sampling, the YOY (Year Class 0) clams exhibited a mean density of $6.2 \mathrm{~m}^{-2}\left(\mathrm{SD}=7.0 \mathrm{~m}^{-2}\right)$ in the control area and $1231 \mathrm{~m}^{-2}$ $\left(\mathrm{SD}=2584 \mathrm{~m}^{-2}\right)$ in the impact zone (Table 2). The far higher recruitment in the spill area could be explained as a consequence of: (1) greater survival after settlement where predators like sea stars, moon snails, and rock crabs had been decimated by the spill; (2) a serendipitous consequence of patchiness in recruitment and the lack of replication of transects in this study; or (3) evidence of a geographic cline in settlement rate from highs near the point of land at the east where grounding occurred to lows toward the west where the control area was located. We used surf clam density data from the control area to estimate pre-spill densities in estimation of mortality. To the degree that clam recruitment to this western area is systematically lower than to the spill area, this decision resulted in conservative estimates of surf clam losses.

Survivorship of young clams. Subsequent sampling from December 1997 to February 1998 (ca. 2 yr postspill) provided further insight into the surf clam demography in this area of the Rhode Island coast. Dredge samples contained the previously detected cohort of now 1.5 yr-old clams (2.5 to $7.5 \mathrm{~cm}$ in length with a mean of $5.6 \mathrm{~cm}$ ) plus a new cohort of presumably 0.5 yr-old recruits $(<2.5 \mathrm{~cm})$. By comparing densities only in re-sampled stations in the control area of almost 1 yr-olds in May/June 1997 to 1.5 yr-olds from December 1997 to February 1998 (Table 2), we computed a 7 -mon survival rate of $6.3 \%$, which translates to an annual rate of $0.88 \%$. We rounded that value up for our subsequent demographic modeling and assumed a $1 \%$ annual survival rate for surf clams from Age 0.5 to 1.5 , or $10 \%$ per half year in this period (Table 3 ). The sampling data provided a separate confirmation of this early life-stage mortality rate. Multiplying by the correction factor (17) to adjust for undercounting of YOY clams in dredge samples at the 3 control area stations that were re-sampled from December 1997 to February 1998 yielded an estimated YOY $\left(0.5\right.$ yr-old) density of $2.72 \mathrm{~m}^{-2}$ (Table 3 ). Application of a $1 \%$ annual survival rate would yield an expected 1.5 yr-old density in this cohort of $0.027 \mathrm{~m}^{-2}$. The actual density of 1.5 yr-olds in the December 1997 to February 1998 sampling was $0.04 \mathrm{~m}^{-2}$. 
Table 2. Mean grain size $(\mathrm{mm})$ and measured surf clam Spisula solidissima density (ind. $\mathrm{m}^{-2}$ ) along the indicated transects (see Fig. 1) in dredge samples (15 replicates per station) taken in the spring of 1997 and winter 1997/98. Transects designated by $\mathrm{W}$ are in the impacted area, whereas FW indicates the control area. Transect $\mathrm{W}-\mathrm{R}$ is a re-sampling of the $\mathrm{W}$ transect

\begin{tabular}{|c|c|c|c|c|c|}
\hline Transect & $\begin{array}{l}\text { Depth } \\
\text { (m) }\end{array}$ & $\begin{array}{l}\text { Date sampled } \\
\text { (dd/mm/yy) }\end{array}$ & $\begin{array}{c}\text { Grain } \\
\text { size }(\mathrm{mm})\end{array}$ & $\begin{array}{c}\text { Density } \\
\text { Mean (SD) }\end{array}$ & Year class \\
\hline W & 3 & $28 / 05 / 97$ & 0.1 & $472.9(93.0)$ & 0 (1996) \\
\hline W & 4 & 08/06/97 & 0.1 & $337.9(94.6)$ & 0 (1996) \\
\hline W & 6 & $12 / 06 / 97$ & 0.1 & $254.6(42.3)$ & 0 (1996) \\
\hline W-R & 3 & $12 / 01 / 98$ & 0.1 & $110.5(31.8)$ & 1 (1996) \\
\hline W-R & 4 & $21 / 12 / 97$ & 0.1 & $13.80(7.4)$ & 1 (1996) \\
\hline W-R & 6 & $15 / 01 / 98$ & 0.2 & $3.30(1.6)$ & 1 (1996) \\
\hline W & 8 & $29 / 05 / 97$ & 1.1 & $2.44(1.3)$ & 0 (1996) \\
\hline $\mathrm{W}$ & 10 & $31 / 05 / 97$ & 2.1 & $0.80(1.3)$ & 0 (1996) \\
\hline W1 & 3 & $10 / 12 / 97$ & 0.1 & $1.00(0.9)$ & 0 (1997) \\
\hline W1 & 4 & $15 / 12 / 97$ & 0.1 & $1.80(1.3)$ & 0 (1997) \\
\hline W1 & 6 & $11 / 12 / 97$ & 0.6 & $1.50(1.4)$ & 0 (1997) \\
\hline W1 & 8 & $12 / 12 / 97$ & 1.1 & $0.00(0)$ & \\
\hline W1 & 10 & $13 / 12 / 97$ & 1.0 & $0.00(0)$ & \\
\hline W2 & 3 & $03 / 12 / 97$ & 0.2 & $0.90(1.1)$ & 1 (1996) \\
\hline W2 & 4 & 05/12/97 & 0.3 & $0.00(0)$ & 0 (1997) \\
\hline W2 & 6 & 06/12/97 & 0.4 & $0.80(0.9)$ & 0 (1997) \\
\hline W2 & 8 & 08/12/97 & 0.8 & $3.70(2.0)$ & 0 (1997) \\
\hline W2 & 10 & 09/12/97 & 1.0 & $1.60(1.3)$ & 0 (1997) \\
\hline W3 & 3 & $25 / 11 / 97$ & 1.6 & $0.00(0)$ & \\
\hline W3 & 4 & $26 / 11 / 97$ & 0.8 & $0.00(0)$ & \\
\hline W3 & 6 & $28 / 11 / 97$ & 1.2 & $0.00(0)$ & \\
\hline W3 & 8 & 29/11/97 & 1.0 & $1.30(0.7)$ & 0 (1997) \\
\hline W3 & 10 & $30 / 11 / 97$ & 1.7 & $0.10(0.2)$ & 0 (1997) \\
\hline W4 & 3 & $11 / 11 / 97$ & 0.2 & $8.30(3.3)$ & 1 (1996) \\
\hline W4 & 4 & $12 / 11 / 97$ & 0.2 & $17.10(7.2)$ & 1 (1996) \\
\hline W4 & 6 & $18 / 11 / 97$ & 0.1 & $11.80(9.2)$ & 1 (1996) \\
\hline W4 & 8 & $19 / 11 / 97$ & 0.8 & $3.90(1.4)$ & 0 (1997) \\
\hline W4 & 10 & $24 / 11 / 97$ & 0.4 & $2.50(2.3)$ & 0 (1997) \\
\hline FW & 3 & $15 / 06 / 97$ & 0.3 & $1.33(1.5)$ & 0 (1996) \\
\hline FW & 4 & $16 / 06 / 97$ & 0.2 & $1.07(1.2)$ & 0 (1996) \\
\hline FW & 6 & $14 / 06 / 97$ & 0.1 & $0.53(0.6)$ & 0 (1996) \\
\hline FW & 8 & $17 / 06 / 97$ & 0.1 & $0.07(0.3)$ & 0 (1996) \\
\hline FW & 10 & $18 / 06 / 97$ & 0.1 & $0.33(0.6)$ & 0 (1996) \\
\hline FW1 & 3 & $20 / 01 / 98$ & 0.8 & $0.00(0)$ & \\
\hline FW1 & 4 & $21 / 01 / 98$ & 0.6 & $0.00(0)$ & \\
\hline FW1 & 6 & $22 / 01 / 98$ & 0.3 & $0.10(0.2)$ & 0 (1997) \\
\hline FW1 & 8 & 02/02/98 & 0.7 & $0.20(0.4)$ & 0 (1997) \\
\hline FW1 & 10 & 03/02/98 & 0.4 & $0.00(0)$ & \\
\hline FW2 & 3 & $20 / 12 / 97$ & 0.3 & $0.30(0.5)$ & 0 (1997) \\
\hline FW2 & 4 & $20 / 02 / 98$ & 0.4 & $0.80(0.9)$ & 0 (1997) \\
\hline FW2 & 6 & $22 / 02 / 98$ & 0.6 & $0.30(0.5)$ & 0 (1997) \\
\hline FW2 & 8 & $21 / 02 / 98$ & 0.5 & $0.40(0.5)$ & 0 (1997) \\
\hline FW2 & 10 & $23 / 02 / 98$ & 0.8 & $0.00(0)$ & \\
\hline
\end{tabular}

rates taken from the literature (see below), and averaged the 2 yr of data. From the May/ June 1997 sampling, we chose the mean abundance of YOY clams from the core sampling (Table 1) and projected that backwards in time by $0.5 \mathrm{yr}$ to provide one estimate of YOY clam abundance for the date of the spill. Across all the control core samples, YOY density averaged $12 \mathrm{~m}^{-2}$, which after application of a half-year survivorship of $10 \%$ represents survivors expected from 120 0.5 yr-olds in January 1996 (Table 3). Based on this YOY abundance and estimated survivorship rates, the control area contained an estimated 5.52 older clams $\mathrm{m}^{-2}$, with the size distribution shown in Table 3. Similarly, the observed density of 0.5 yr-old clams sampled in the control area from December 1997 to February 1998 was 2.72 m $^{-2}$ (corrected for dredge sampler error as explained above). Assuming the survivorship schedule and stable age distribution in Table 3, the density of older clams during this second period was $0.13 \mathrm{~m}^{-2}$. To derive our estimate of surf clam densities by age (size) class at the time of the spill (January 1996), we averaged across these 2 yr the densities in each age class, weighting by sampling effort (Table 3). This weighting had the effect of undervaluing the clams that settled in the year just after the oil spill, perhaps appropriate if residual negative effects of the spill persisted.

The resulting average densities computed from the site-specific sampling data (Table 3) match available published data in the literature reasonably well. Weighted averages of the 2 samplings yield a YOY density of $41.8 \mathrm{~m}^{-2}$ and a density of 1.9 older clams $\mathrm{m}^{-2}$, totaling $43.7 \mathrm{~m}^{-2}$ (Table 3). Abundance of older clams $(>3.6 \mathrm{~cm})$ was similar to

Numbers of clams by age class at the time of the spill. We used results of post-spill sampling (Tables $1 \& 2$ ) and our age-specific mortality schedule (see 'Survival' below) to estimate, by size and age class, the densities of surf clams present at the time of the 'North Cape' oil spill. To form our best estimate of densities of surf clams in each age (size) class, we used only the YOY data for each sample year from the control (presumably unaffected) site west of the spill area, computed numbers for older clams using a survivorship schedule based on mortality
Olsen's (1970) observed mean of $1.8 \mathrm{~m}^{-2}$ for that same size class in nearby Rhode Island waters. Franz (1976) observed 25 to $125 \mathrm{YOY} \mathrm{m}^{-2}$ in August on the south coast of eastern Long Island, ca. $50 \mathrm{~km}$ from the spill site, with the greater numbers farther to the west toward the Rhode Island coast.

Ecotoxicological impact assessment modeling. Mortality of surf clams and other bivalves was estimated by application of ecotoxicological impact assessment modeling (French \& Rines 1998, French McCay 2002, 
Table 3. Spisula solidissima. Age-specific growth and mortality of surf clams used to develop predictions of abundances prior to the 'North Cape' oil spill in Rhode Island. Projections are made for the half-year to match the season (winter) of the oil spill. Length-weight relationships were from Weinberg \& Hesler (1996). Survival rates were taken from a literature review and cohort analysis (see 'Survival' in text). The first column of density estimates is based upon core sampling data of $1 \mathrm{yr}$-old clams taken in May/June 1997, and the second column on dredge sampling data of 0.5 yr-old clams taken in December 1997 to February 1998. Actual observations are presented in bold while others are projected by applying the age-specific survivorship schedule. The final column is the effort-weighted mean of the first 2 estimates.YOY: young-of-the-year $(0.5 \mathrm{yr}$-old at time of spill)

\begin{tabular}{|c|c|c|c|c|c|c|}
\hline \multirow[t]{2}{*}{ Age $(y r)$} & \multirow{2}{*}{$\begin{array}{l}\text { Shell } \\
\text { length } \\
(\mathrm{cm})\end{array}$} & \multirow{2}{*}{$\begin{array}{c}\text { Meat } \\
\text { weight } \\
(\mathrm{g})\end{array}$} & \multirow{2}{*}{$\begin{array}{c}\text { Survival } \\
\text { to next } \\
\text { class }\end{array}$} & \multicolumn{3}{|c|}{ Density estimates (ind. $\mathrm{m}^{-2}$ ) } \\
\hline & & & & $\begin{array}{l}\text { May/ } \\
\text { June } \\
1997\end{array}$ & $\begin{array}{c}\text { Dec } 1997 \\
\text { to } \\
\text { Feb } 1998\end{array}$ & $\begin{array}{l}\text { Weighted } \\
\text { mean }\end{array}$ \\
\hline 0.5 & 1.0 & 0.130 & 0.10 & 120 & 2.72 & 41.8 \\
\hline 1 & 1.5 & 0.371 & 0.10 & 12 & 0.272 & 4.18 \\
\hline 1.5 & 3.6 & 3.54 & 0.50 & 1.20 & 0.027 & 0.42 \\
\hline 2.5 & 6.2 & 14.2 & 0.905 & 0.60 & 0.014 & 0.21 \\
\hline 3.5 & 8.2 & 29.6 & 0.905 & 0.54 & 0.012 & 0.19 \\
\hline 4.5 & 9.8 & 47.0 & 0.905 & 0.49 & 0.011 & 0.17 \\
\hline 5.5 & 11.1 & 64.5 & 0.905 & 0.44 & 0.010 & 0.15 \\
\hline 6.5 & 12.1 & 80.8 & 0.861 & 0.40 & 0.009 & 0.14 \\
\hline 7.5 & 12.9 & 95.3 & 0.861 & 0.35 & 0.008 & 0.12 \\
\hline 8.5 & 13.5 & 107.9 & 0.861 & 0.30 & 0.007 & 0.10 \\
\hline 9.5 & 14.1 & 118.6 & 0.861 & 0.26 & 0.006 & 0.09 \\
\hline 10.5 & 14.5 & 127.6 & 0.861 & 0.22 & 0.005 & 0.08 \\
\hline 11.5 & 14.8 & 134.9 & 0.861 & 0.19 & 0.004 & 0.07 \\
\hline 12.5 & 15.0 & 140.9 & 0.861 & 0.16 & 0.004 & 0.06 \\
\hline 13.5 & 15.2 & 145.8 & 0.861 & 0.14 & 0.003 & 0.05 \\
\hline 14.5 & 15.4 & 149.8 & 0.861 & 0.12 & 0.003 & 0.04 \\
\hline 15.5 & 15.5 & 153.0 & 0.861 & 0.10 & 0.002 & 0.04 \\
\hline \multicolumn{4}{|c|}{ YOY at time of spill } & 120.0 & 2.72 & 41.8 \\
\hline \multicolumn{4}{|c|}{ Total $>3.6 \mathrm{~cm}$ at time of spill } & 5.52 & 0.13 & 1.92 \\
\hline \multicolumn{4}{|c|}{ Total at time of spill } & 125.5 & 2.85 & 43.7 \\
\hline
\end{tabular}

2003), which involved coupling a temporal physical fates model of transport and degradation of PAHs with a biological effects model to predict acute toxic mortality for different taxa. Field sampling of PAH concentrations in the water column was conducted to validate the model's time-dependent predictions of exposure. Side-scan sonar was used to map the areas of softbottom (which is all fine-to-coarse sand) and rocky reef habitats in the spill-affected area, which allowed modeling to be stratified by location and amount of habitat (French McCay 2003). Published information on variation in acute mortality with exposure (French McCay 2002) was then applied together with available information on natural pre-spill densities and size distributions to predict total loss of abundance and biomass for key taxa (French \& Rines 1998, French McCay 2003).

Exposure concentrations of PAHs in bottom water were validated and the biological effects model originally validated for lobsters (French McCay 2003) was applied to bivalves offshore from the beach (French McCay 2003) and in salt ponds (French \& Rines 1998) because bivalves and juvenile lobsters suffer similar toxic effects by narcosis (French McCay 2002). Computation of initial loss of biomass from acute mortality required estimates of prespill abundance, size distribution, and size-biomass relationships for each bivalve, while subsequent computation of production forgone required estimates of expected growth and mortality rates (French McCay 2003). The modeling for the salt ponds included a separate but linked model of temporal change in PAH concentrations (Hinga 1997) in which source PAH concentrations were provided by the ocean model (French McCay 2003) and the rate of decline of concentrations were fitted to pond observations (Hinga 1997). Then exposure and mortality of bivalves was estimated from application of the same biological effects model used for the ocean to salt-pond abundance estimates derived from literature reviews (French \& Rines 1998, French McCay 2003).

Results of this ecotoxicological impact assessment modeling exercise (Table 4) demonstrated that surf clams comprised the vast majority (ca. $88 \%$ by number and $96 \%$ as biomass) of the bivalves killed after the 'North Cape' oil spill. Contributions from other species (blue mussels, hard clams, softshell clams, oysters, and bay scallops)were all relatively small. When the estimated surf clam density (Table 3) was entered into the biological effects model, the total number of older ( $>1 \mathrm{yr}$ ) dead surf clams predicted by the ecotoxicological impact assessment was 2.6 million (Table 4), which is larger than Gibson's (1997) computed value of 1.8 million stranded surf clams. Not all dead surf clams would be stranded on the beaches, so the larger number of dead predicted by the model is reasonable. The model predicted a total loss (all ages) of 150 million surf clams, representing a biomass of $193000 \mathrm{~kg}$ (Table 4). All other bivalves added only another $8000 \mathrm{~kg}$ of additional biomass losses at the time of the spill.

Demographic modeling to compute production forgone. Estimates of age-specific growth, the relationship of clam size to biomass, age-specific mortality schedule, and the numbers of clams killed in each age class were required to estimate production forgone. For most of the individual and population demographic parameters, a synthesis of available literature provided 
Table 4. Summary of estimates of bivalve losses resulting from the 'North Cape' oil spill. Losses are based upon application of ecotoxicological impact assessment modeling: marine (French McCay et al 2003) and salt pond (French \& Rines 1998). Production forgone is the expected summed somatic growth in the absence of the spill. Total loss is biomass killed plus production forgone, with future losses discounted at $3 \%$ annually. YOY: young-of-the-year $(0.5 \mathrm{yr}$-old at time of spill)

\begin{tabular}{|c|c|c|c|c|}
\hline $\begin{array}{l}\text { Location } \\
\text { Species category }\end{array}$ & $\begin{array}{l}\text { Numbers } \\
\text { killed } \\
\text { (thousands) }\end{array}$ & $\begin{array}{c}\text { Biomass } \\
\text { killed } \\
(\mathrm{kg})\end{array}$ & $\begin{array}{l}\text { Production } \\
\text { forgone } \\
(\mathrm{kg})\end{array}$ & $\begin{array}{l}\text { Total loss of } \\
\text { production } \\
(\mathrm{kg})\end{array}$ \\
\hline \multicolumn{5}{|l|}{ Coastal marine } \\
\hline $\begin{array}{l}\text { Hard clam } \\
\text { Mercenaria mercenaria }\end{array}$ & 37 & 7 & 798 & 805 \\
\hline $\begin{array}{l}\text { Surf clam } \\
\text { Spisula solidissima (total) }\end{array}$ & 150588 & 192496 & 171516 & 364013 \\
\hline $\begin{array}{l}\text { YOY } \\
>1 \mathrm{yr}\end{array}$ & $\begin{array}{r}148010 \\
2578\end{array}$ & $\begin{array}{r}19241 \\
173255\end{array}$ & $\begin{array}{r}64963 \\
106554\end{array}$ & $\begin{array}{r}84204 \\
279809\end{array}$ \\
\hline $\begin{array}{l}\text { Blue mussel } \\
\text { Mytilus edulis }\end{array}$ & 20247 & 879 & 1203 & 2082 \\
\hline Total bivalves & 170872 & 193382 & 173517 & 366900 \\
\hline \multicolumn{5}{|l|}{ Salt pond } \\
\hline $\begin{array}{l}\text { Soft-shell clam } \\
\text { Mya arenaria }\end{array}$ & 499 & 5712 & 3888 & 9600 \\
\hline $\begin{array}{l}\text { American oyster } \\
\text { Crassostrea virginica }\end{array}$ & 149 & 1857 & 905 & 2762 \\
\hline $\begin{array}{l}\text { Bay scallop } \\
\text { Argopecten irradians }\end{array}$ & 0.159 & 5 & 0 & 5 \\
\hline Total bivalves & 649 & 7573 & 4794 & 12367 \\
\hline Total & 171521 & 200955 & 178311 & 379267 \\
\hline
\end{tabular}

appropriate values, while others were from analysis of samples collected in the spill area (Tables 1 \& 2). Estimation of the numbers killed by age (size) class came from application of the biological effects ecotoxicology model (French McCay 2003) after estimation of the numbers of clams in each age (size) class present at the time of the oil spill (Table 3).

Growth. We chose to describe length as a function of age by using the traditional von Bertalanffy growth curve (Ricker 1975):

$$
L_{t}=L_{\infty}\left\{1-\mathrm{e}^{-K\left(t-t_{0}\right)}\right\}
$$

where $L_{t}$ is shell length $(\mathrm{cm})$ at age $t(\mathrm{yr}), L_{\infty}$ is the asymptotic maximum length, $K$ is the Brody growth coefficient, and $t_{0}$ is a constant. Based on Weinberg \& Hesler (1996), we used the following values for surf clams: $L_{\infty}=15.99 \mathrm{~cm}, K=0.232$, and $t_{0}=-0.099$. However, insertion of these parameter values indicates a length of $3.6 \mathrm{~cm}$ at $t=1 \mathrm{yr}$. Based on Weissberger (1998), $3.6 \mathrm{~cm}$ clams would be well into their second year of life, and we assumed that age $t$ represents a nominal age (actual age in years minus 0.5) in our application of the von Bertalanffy growth curve. This calibration also had the advantage of assessing abundances at mid winter (the half birthdays), coinciding with when the spill occurred. Conversion of shell length to weight was achieved by applying the following equation with parameters from Fay et al. (1983):

$$
W_{t}=\mathrm{a} L_{t}^{\mathrm{b}}
$$

where $W_{t}$ is wet meat weight at age $t$ (yr) and $\mathrm{a}$ and $\mathrm{b}$ are constants $(\mathrm{a}=$ 0.0001304 and $b=2.578$, for surf clam length in $\mathrm{cm}$ and weight in $\mathrm{kg}$, Table 3).

Survival. To describe age-specific survival, we adopted the basic exponential fisheries population dynamics model of Ricker (1975). For surf clams of legally harvestable size, the number at age $t(\mathrm{yr}), N_{t}$, is a function of the number of new recruits to the fishery at age $t_{\mathrm{r}}$ years. For $t>t_{\mathrm{r}}$ :

$$
\begin{gathered}
N_{t}=R \mathrm{e}^{-Z_{\mathrm{A}}\left(t-t_{\mathrm{r}}\right)} \\
Z_{\mathrm{A}}=M+F
\end{gathered}
$$

where $Z_{\mathrm{A}}$ is annual instantaneous total mortality (assumed constant for ages $\left.t>t_{\mathrm{r}}\right), M$ is annual instantaneous natural mortality, $F$ is annual instantaneous fishing mortality, and $R$ is the number of individuals in this cohort that first recruited to the fishable population (i.e. $R=$ number at age $t_{\mathrm{r}} \mathrm{yr}$ ). For $t \leq t_{\mathrm{r}}$ :

$$
N_{t}=N_{t-1} \mathrm{e}^{-Z_{t}}
$$

where $Z_{t}$ is the age-specific annual instantaneous natural mortality rate. The annual survival rate for age $t\left(S_{t}\right)$ is thus:

$$
S_{t}=\mathrm{e}^{-Z_{t}}
$$

We estimated rates of age-specific mortality of Rhode Island surf clams using information from several sources. Grosselin \& Qian (1997) analyzed the early survival of newly settled clams and determined that only about $1 \%$ of the new settlers would still be alive by winter. Thus, we assumed survival of surf clams from age 0 to $0.5 \mathrm{yr}$ to be $1 \%$. Based on analysis of sampling data for surf clams at the spill site and detailed above, an annual survival rate of $1 \%$, or $10 \%$ per $0.5 \mathrm{yr}$, is assumed to apply from 0.5 to $1.5 \mathrm{yr}$ (Table 3). Instantaneous mortality rates of harvestablesized surf clams $(>12.1 \mathrm{~cm}$ or $>6 \mathrm{yr}$ old $)$ in southern New England have been estimated by NMFS (1995) to be $M=0.05$ and $F=0.1$, giving a total mortality rate $Z=0.15$. Estimated mortality rates for smaller clams are higher, but empirical data are not readily available. Clams reach a size refuge from predation at $5 \mathrm{~cm}$ in length (MacKenzie et al. 1985), or ca. 2 yr of age. Thus, 
we assumed that mortality rates for 2.5 to $5.5 \mathrm{yr}$ olds are $M=0.1$ (twice the rate of larger clams), with $F=0$ (no fishing). For surf clams from 1.5 to $2.5 \mathrm{yr}$ old (3.6 to $6.2 \mathrm{~cm}$ length), we chose an annual survivorship of $50 \%$, halfway between that of younger and older age classes (Table 3).

Computation of production forgone. In addition to the estimated direct kill of 148 million YOY plus 2.6 million older clams, weighing (without shells) a total of $192500 \mathrm{~kg}$ (Table 4), the total production loss must also include production forgone, which is the somatic growth those clams would be expected to have achieved over their remaining natural lifespan. The equations used to calculate the expected remaining lifetime production $\left(P_{\mathrm{L}}\right)$ are:

$$
\begin{aligned}
& P_{\mathrm{L}}=\sum \sum N_{i, y} S_{i+y}\left(W_{i+y+1}-W_{i+y}\right) /(1+d)^{y} \\
& N_{i+1, y+1}=N_{i, y} S_{i+y}=N_{i, y} \mathrm{e}^{-\left(M_{i}+y+F_{i}+y\right)}
\end{aligned}
$$

where $N_{i, Y}$ is the number of Age Class $i$ expected to have remained alive at the beginning of year $y$ after the spill, $S_{i+y}$ is the expected portion of Age Class $i$ surviving from Age $i+y$ to $i+y+1, W_{i+y}$ is the weight per individual for Age Class $i$ at $y$ years after the spill, $M_{i+y}$ is instantaneous annual natural mortality rate, $F_{i+y}$ is instantaneous annual fishing mortality rate (both for Age $i+y)$, and $d$ is the discount rate $(d=0.03$ : NOAA 1997). Before the age of recruitment, fishing mortality is 0 . The discount factor, $1 /(1+d)^{y}$, decreases the value of the production by $3 \%$ for each year that passes before that production would have been realized. This follows the economic model that losses, or gains of restoration, in the future are less valued than present production. Including identical discounting on both the injury and restoration sides of the equation allows time lags in both losses and benefits to be appropriately treated so as to measure values lost and gained fixed to a common year.

\section{RESULTS}

\section{Injury}

The total loss of surf clam production from the 'North Cape' oil spill was 364000 kg (192500 kg killed directly and $171500 \mathrm{~kg}$ in production foregone). Injuries to all bivalves in the marine environment and the salt ponds were computed in an identical fashion (French \& Rines 1998, French McCay 2003) and are summarized in Table 4. Although these projections of injuries for other bivalve species did not have benefit of site-specific sampling data, the dominance of the surf clam loss means that the total loss of bivalve production is not greatly biased by errors in estimating pre-spill densities of rare species. The total loss of bivalve production caused by the 'North Cape' oil spill was thereby estimated to be $379000 \mathrm{~kg}$ (Table 4). This represents the injury that restoration should be scaled to replace.

\section{Scale of compensatory restoration}

The quantitative benefits of restoration, whether it be via hatchery stocking, transplantation, reduction of fishing, or habitat restoration, can be estimated by the net bivalve production that is added to the ecosystem. Use of this metric to establish the scale of the restoration project required to compensate for the loss must use the same currency (bivalve production discounted to a common year) that was used to quantify the loss. Secondary production represents one fundamental ecosystem process, so using this as a proxy for all ecosystem services has some justification. Furthermore, production of suspension-feeding bivalves correlates with their important filtration and biochemical processing functions. Other important ecosystem functions of bivalves may not be well measured by production alone. For example, the size structure of the lost animals is not necessarily reproduced in a restoration that matches the loss using production as the sole criterion. Smaller individuals provide an ecosystem service of feeding demersal predators, especially crabs, whereas older bivalves find substantial refuge from predation (e.g. Kennedy et al. 1996, Kraeuter 2001). Thus biasing the restoration action by using larger bivalves could add stability to the population dynamics by serving as a long-lasting spawning sanctuary and would provide similar filtration on phytoplankton but at the expense of failing to pass the energy produced up the food chain.

The process of estimating gains in production from any of the potential restoration approaches involves use of the same computations developed to estimate production forgone. In this case, we apply the identical equations derived above to project demographics and individual growth into the future, not to quantify production that would have occurred absent losses but instead to predict production that will occur through augmentation of abundance of one or more age (size) classes. Again analogous to the method for quantifying loss of production, we add the biomass of any individuals added to start the restoration to the discounted future production expected before they die to compute the total net enhancement of production. Using the identical method for estimating both the loss and gain is appropriate to insure that the scaling of restoration matches, and thus compensates for, the magnitude of the injury. 
The choice of species to use in the bivalve restoration does not affect the method of estimation of quantitative gain in production, just the parameter values used in the projection. Many considerations enter into this choice, including reliability of the technology for each species, availability of a source (for stocking or seed production), cost effectiveness, and the distribution of losses among species. Assuming that all suspension-feeding bivalves are equivalent and interchangeable in restoring losses may compensate for lost production, filtration, and biogeochemical processing but does not necessarily replace those functions in the same habitat (here coastal ocean vs. salt pond). In addition, not all bivalves are of equal value to the ecosystem or to humans in fisheries. We scaled the restoration required for several alternative choices of bivalve species and size class within species (Table 5). We considered the American oyster Crassostrea virginica, bay scallop Argopecten irradians, hard clam Mercenaria mercenaria, and soft-shell clam Mya arenaria, as well as the surf clam Spisula solidissima. The same demographic model described above was used for each species, but different specific life-history parameters were used (Tables 5 \& 6). For hard clams and oysters, we also made these scaling projections with and without fishing pressure to quantify the contributions of establishing fishing sanctuaries. Each alternative was scaled to compensate for the loss of $379000 \mathrm{~kg}$ of bivalves, providing the numbers of individuals initially required to seed, transplant, protect from the fishery, or produce by habitat restoration. Each of the life-history parameters is estimated with uncertainty and a thorough analysis of benefits of restoration could include a formal uncertainty analysis to aid in choosing the most appropriate restoration option. We do not do so here because we use these results merely to illustrate general patterns. For oysters, we employ several different natural mortality rates (Table 5) because our estimates of their demographic rates are the most uncertain, fluctuating with disease incidence and severity.

The results of these computations to scale restoration options reveal several patterns. First, the larger the individuals added through seeding (or stocking, protecting, etc.), the fewer are needed. This outcome is illustrated best by hard clam results, where numerous starting sizes were modeled (Table 5). The numbers required do not decrease linearly with size but instead show a sharp early increase and then a far slower change for larger, older clams which experience lower natural mortality rates (e.g. Peterson et al. 1995). If the animals are from a hatchery, the costs of rearing seed to larger size are far higher, so cost efficiency would require survivorship gains to be balanced against increased costs to choose the optimal size to add. Sec- ond, for hard clams, protection from fishing can enhance the expected benefits of the restoration more than for any other species modeled (Table 5). This result follows from the longer natural life span of this species, which allows for greater expected growth in the future. Third, the calculations reveal that future production of oysters is highly sensitive to mortality rate. For oysters subject to fishing pressure, the number of seed oysters required to provide $179000 \mathrm{~kg}$ of production increased from 29 to 122 million as $M$ was increased from 0.223 to $0.50 \mathrm{yr}^{-1}$ (Table 5). Fourth, if seeding is restricted to relatively small (and less expensive) individuals (e.g. $<3.3 \mathrm{~cm}$ in length), the most efficient restoration can come from choosing surf clams, requiring only 5.3 million as compared to 16 to 75 million hard clams, 25 to 122 million oysters, 32 million bay scallops, and 26 to 218 million soft-shell clams (Table 5).

\section{DISCUSSION}

Accomplishment of the compensatory net gain in bivalve production requires that the restored species is limited by factors addressed by the restoration actions and that restoration is successful. These issues, along with practical matters concerning logistics, were considered in developing the restoration plan for providing the required compensation for the effects of the oil spill considered here as an example. In the following sections, we briefly discuss what is known about limitations to bivalve production and the effectiveness of the 4 specific restoration approaches that were considered.

\section{Limitation of bivalve population size and production}

Because of their commercial value, there is a substantial body of scientific information on such species as surf clams Spisula solidissima, hard clams Mercenaria mercenaria, American oysters Crassostrea virginica, and bay scallops Argopecten irradians. They are appealing candidates for restoration because of their general historical decline in abundance in the southern New England region, their value as natural biological filters of over-fertilized and eutrophied systems, their human use value for exploitation, and their ecological importance as prey for marine predators like crabs and bottom fishes. While surf clams experienced the greatest loss in production from the 'North Cape' oil spill, enhancement of these ecologically similar species was considered because they provide analogous filtration services and other functions within the ecosystem. 
Table 5. Numbers of additional individuals required to compensate quantitatively for production lost (379267 kg) from the oil spill. Results are derived from application of the age-specific survivorship and growth models (see 'Survival' in text). Computations vary bivalve species, size class added, fishing pressure, and (for oysters) mortality rate. $M$ is instantaneous exponential rate of natural mortality, $F$ is instantaneous exponential rate of fishing mortality (French et al. 1996). Mortality rate from Age 0 to 1 yr is assumed to be $10 \%$ (Grosslein \& Qian 1997). Length at age and length-weight parameters $(L, W)$ are from: $(1)$ Weinberg \& Hesler (1996) and Fay et al. (1983); (2) French et al. (1996); and (3) Rice et al. (1989)

\begin{tabular}{|c|c|c|c|c|c|c|c|c|c|c|}
\hline Species & $\begin{array}{c}M \\
\left(\mathrm{yr}^{-1}\right)\end{array}$ & $\begin{array}{c}F \\
\left(\mathrm{yr}^{-1}\right)\end{array}$ & $\begin{array}{l}\text { Age of } \\
\text { recruit- } \\
\text { ment to } \\
\text { fishery }\end{array}$ & $\begin{array}{l}\text { Length } \\
\text { (cm) }\end{array}$ & $\begin{array}{c}\text { Meat } \\
\text { weight } \\
\text { (g) }\end{array}$ & $\begin{array}{c}\text { Age } \\
\left(\mathrm{yr}^{-1}\right)\end{array}$ & $\begin{array}{l}\text { Lifetime } \\
\text { production } \\
(\mathrm{kg} / \mathrm{kg})\end{array}$ & $\begin{array}{c}\text { Lifetime } \\
\text { production }+ \\
\text { initial biomass } \\
\left(\mathrm{kg} \mathrm{ind} .^{-1}\right)\end{array}$ & $\begin{array}{l}\text { Nos. of ind. } \\
\text { required for } \\
\text { compensation } \\
\text { (millions) }\end{array}$ & $\begin{array}{l}\text { Source } \\
\text { for } L, W\end{array}$ \\
\hline $\begin{array}{l}\text { Surf clam Spisula } \\
\text { solidissima }\end{array}$ & 0.12 & 0.03 & 6 & 3.0 & 1.42 & 1 & 49.61 & 0.0719 & 5.3 & (1) \\
\hline $\begin{array}{l}\text { Surf clam Spisula } \\
\text { solidissima }\end{array}$ & 0.12 & 0.03 & 6 & 1.5 & 0.065 & 0 & 107.3 & 0.0070 & 54 & (1) \\
\hline $\begin{array}{l}\text { Hard clam Merce- } \\
\text { naria mercenaria }\end{array}$ & 0.1 & 0.3 & 3 & 2.0 & 1.1 & 0 & 4.235 & 0.0058 & 66 & (2) \\
\hline $\begin{array}{l}\text { Hard clam Merce- } \\
\text { naria mercenaria }\end{array}$ & 0.1 & 0 & 3 & 2.0 & 1.1 & 0 & 7.131 & 0.0090 & 42 & (2) \\
\hline $\begin{array}{l}\text { Hard clam Merce- } \\
\text { naria mercenaria }\end{array}$ & 0.1 & 0.3 & 3 & 2.0 & 1.1 & 0 & 19.94 & 0.0231 & 16 & $(2)$ \\
\hline $\begin{array}{l}\text { Hard clam Merce- } \\
\text { naria mercenaria }\end{array}$ & 0.1 & 0 & 3 & 5.8 & 22.4 & 4 & 1.305 & 0.0517 & 7.3 & $(2)$ \\
\hline $\begin{array}{l}\text { Hard clam Merce- } \\
\text { naria mercenaria }\end{array}$ & 0.1 & 0 & 3 & 7.5 & 46.4 & 7 & 0.291 & 0.0599 & 6.3 & $(2)$ \\
\hline $\begin{array}{l}\text { Hard clam Merce- } \\
\text { naria mercenaria }\end{array}$ & 0.1 & 0 & 3 & 8.5 & 66.2 & $>18$ & 0.010 & 0.0668 & 5.7 & (2) \\
\hline $\begin{array}{l}\text { Hard clam Merce- } \\
\text { naria mercenaria }\end{array}$ & 0.1 & 0 & 3 & 7.8 & 50.9 & 17 & 0.383 & 0.0704 & 5.4 & (3) \\
\hline $\begin{array}{l}\text { Hard clam Merce- } \\
\text { naria mercenaria }\end{array}$ & 0.1 & 0 & 3 & 8.5 & 66.0 & 17 & 0.164 & 0.0768 & 4.9 & (3) \\
\hline $\begin{array}{l}\text { American oyster } \\
\text { Crassostrea virginica }\end{array}$ & 0.223 & 0 & 2 & 2.0 & 0.40 & 1 & 36.62 & 0.0150 & 25 & (2) \\
\hline $\begin{array}{l}\text { American oyster } \\
\text { Crassostrea virginica }\end{array}$ & 0.223 & 0.3 & 2 & 2.0 & 0.40 & 1 & 31.51 & 0.0130 & 29 & $(2)$ \\
\hline $\begin{array}{l}\text { American oyster } \\
\text { Crassostrea virginica }\end{array}$ & 0.357 & 0 & 2 & 2.0 & 0.40 & 1 & 27.35 & 0.0113 & 33 & $(2)$ \\
\hline $\begin{array}{l}\text { American oyster } \\
\text { Crassostrea virginica }\end{array}$ & 0.357 & 0.3 & 2 & 2.0 & 0.40 & 1 & 24.48 & 0.0102 & 37 & $(2)$ \\
\hline $\begin{array}{l}\text { American oyster } \\
\text { Crassostrea virginica }\end{array}$ & 0.5 & 0.3 & 2 & 2.0 & 2.00 & 0 & 0.552 & 0.0031 & 122 & $(2)$ \\
\hline $\begin{array}{l}\text { Bay scallop Argo- } \\
\text { pecten irradians }\end{array}$ & 0.1 & 1 & 1 & 5.4 & 24.90 & 1 & 0.185 & 0.0295 & 13 & $(2)$ \\
\hline $\begin{array}{l}\text { Bay scallop Argo- } \\
\text { pecten irradians }\end{array}$ & 0.1 & 1 & 1 & 2.0 & 10.00 & 0 & 0.194 & 0.0119 & 32 & (2) \\
\hline $\begin{array}{l}\text { Soft-shell clam } \\
\text { Mya arenaria }\end{array}$ & 0.1 & 0.6 & 2 & 1.5 & 0.35 & 0 & 4.040 & 0.0017 & 218 & (2) \\
\hline $\begin{array}{l}\text { Soft-shell clam } \\
\text { Mya arenaria }\end{array}$ & 0.1 & 0.6 & 2 & 3.3 & 3.07 & 1 & 3.758 & 0.0146 & 26 & (2) \\
\hline
\end{tabular}

Spisula solidissima. Although surf clams are targeted in commercial fisheries, less is known about factors that control their abundance and productivity compared with other exploited bivalve species. Its habitat along the high-energy ocean beaches limits access of researchers and challenges ecologists to define the scales of important population processes.
Surf clams have planktotrophic pelagic larvae that are transported as part of the plankton for about $2 \mathrm{wk}$ before settlement begins (Fay et al. 1983). Thus, it is likely that physical flow regimes could limit the abundance of successful settlers and they almost certainly help dictate the patchy spatial patterns of settlement (Olsen 1970, Franz 1976). There is also potential for 
recruitment limitation at low adult densities, but no evidence is available to test this hypothesis. However, the high abundance of settlers that appeared in the impact zone after the 'North Cape' spill suggests that recruitment may not be limiting in that locality.

Like other benthic bivalves settling into soft sediments (Grosselin \& Qian 1997), surf clams suffer very high losses to predators until they reach a length of about $5 \mathrm{~cm}$, which does not occur until around Age 2 yr (MacKenzie et al. 1985). The predators that are most important in controlling survival and thus production of surf clams are naticid gastropods and various crabs (Weissberger 1998). Demersal fishes may have important effects in reducing abundance of juvenile surf clams in some situations, whereas flounders act to limit growth rates by nipping siphons of larger clams, forcing them use energy for regeneration. High local Spisula density also acts to reduce growth rate, presumably by grazing down food concentrations in the benthic boundary layers (Weinberg \& Hesler 1996). Fishing mortality $(F)$ begins at ca. Age 6 yr and is estimated to be $\leq 0.1$ (NMFS 1995, Table 5), not as intense as some other fisheries. Thus, the intense predation on juvenile clams up to ca. Age 2 yr appears to represent the strongest control on surf clam abundance and production. This suggests that stocking with small clams (Table 5) would increase surf clam production. Protection from predation might also increase clam production, but at a loss to the food web.

Mercenaria mercenaria. The hard clam is the most similar of the candidate bivalve species considered for restoration in the 'North Cape' case to the surf clam, which made up the bulk of the losses, and so was evaluated in some detail. A recent book (Kraeuter \& Castagna 2001) synthesizes knowledge of hard clam biology, including factors that limit abundance and

Table 6. Bivalve growth parameters used in restoration model calculations. Length at age and length $(\mathrm{cm})$ versus weight $(\mathrm{g})$ parameters $(L, W)$ are from:

(1) French et al. (1996); and (2) Rice et al. (1989). $L_{\infty}$ : asymptotic maximum length; $K$ : Brody growth coefficient; $t_{0}$ : constant (see 'Growth' in text)

\begin{tabular}{|lcccccc|}
\hline Species & $L_{\infty}(\mathrm{cm})$ & $K$ & $t_{0}(\mathrm{yr})$ & $\mathrm{a}(L, W)$ & $\mathrm{b}(L, W)$ & $\begin{array}{c}\text { Source } \\
\text { for } L, W\end{array}$ \\
\hline $\begin{array}{l}\text { Hard clam Merce- } \\
\text { naria mercenaria }\end{array}$ & 8.5 & 0.333 & 0.594 & 0.155 & 2.83 & 1 \\
$\begin{array}{l}\text { Hard clam Merce- } \\
\text { naria mercenaria }\end{array}$ & 8.5 & 0.333 & 0.594 & 0.0723 & 2.81 & 2 \\
$\begin{array}{l}\text { American oyster } \\
\text { Crassostrea virginica } \\
\text { Bay scallop Argo- } \\
\text { pecten irradians }\end{array}$ & 13.7 & 0.551 & -0.365 & 0.087 & 2.21 & 1 \\
$\begin{array}{l}\text { Soft-shell clam } \\
\text { Mya arenaria }\end{array}$ & 8.6 & 0.356 & -0.337 & 0.1100 & 2.82 & 1 \\
\hline
\end{tabular}

production. Gamete production in hard clams increases with size, as in most free-spawning marine invertebrates (Peterson 1986a). Because of their high fecundity, most managers of hard clam fisheries assume no spawner-recruit relationship and so even a small number of spawning adults will be sufficient to provide adequate numbers of larvae to sustain the next generation (e.g. Hancock 1973). However, in North Carolina declining recruitment as a result of reduced spawning stock biomass caused by fishery exploitation implies that hard clams may become recruitment limited when adult spawners fall below some critical biomass (Peterson 2002). Little is known about the control of larval survival and success in hard clams, but the North Carolina case suggests that if densitydependent mortality exists, it is not strong enough to overcome a reduction of around $50 \%$ in spawning stock biomass.

At the time of settlement to bottom sediments, hard clams are susceptible to predation by infaunal predators like flat worms (Watzin 1983), small crustaceans like snapping shrimp (Beal 1983), suspension feeders that filter them from the water column, and depositfeeding invertebrates (Hunt et al. 1987). At natural densities, adult and juvenile hard clams do not effectively limit the success of settlement in their local vicinity through filtration (Peterson 2002). Predation rates are high after settlement up to a length of ca. $2.5 \mathrm{~cm}$, where blue crabs, a major predator, begin to experience lowered efficiency in crushing the shell (Arnold 1984, Peterson 1990, Kraeuter 2001). As larger individuals, hard clams continue to have enemies but predation by whelks (Peterson 1982), stone crabs, and rays (Kraeuter 2001) does not lower overall abundance except in certain habitats and under special conditions. Fishing exploitation is intense on natural populations of hard clams and clearly represents an important control on abundance (Peterson 2002) and population structure (Rice et al. 1989).

Bottom habitat causes very important indirect control of hard clam abundance, operating both on the hydrodynamics of the settlement process and, even more importantly, on risk of predation after settlement. Emergent vegetation in seagrass beds slows currents and induces deposition of suspended particles, including invertebrate larvae (Peterson et al. 1984). After settlement, the seagrass root system provides some structural refuge from burrowing and digging predators, thereby further enhancing hard clam abundance (Peterson 1982, 1986b, Wilson 1990). Conse- 
quently, the extent of seagrass habitat limits the abundance of hard clams indirectly. Even more effective than seagrass as a barrier to predation by the hard clam's most significant enemy, the blue crab, is shell bottom habitat provided by oysters (Castagna \& Kraeuter 1985, Peterson et al. 1995) and other mollusc species. Declines in oyster reefs and oyster shell habitats (Rothschild et al. 1994, Lenihan \& Peterson 1998) have been even greater than the declines in seagrass habitat (Orth \& Moore 1983) over the past century. Consequently, hard clam populations are almost certainly reduced regionally because of this loss in an important refuge from intense predation. However, in Narragansett Bay, Crepidula fornicata covers large areas forming a shell bottom (French et al. 1991), which may in part mitigate the losses of seagrass and oyster reefs and explain the greater abundance of hard clams in that estuary as compared to other New England waters.

Thus, as for surf clams, stocking (or other action to increase abundance) of small hard clams (Table 5) would increase production. Protection from predation, perhaps by habitat restoration, might also increase clam production, but potential loss to the food web should be considered as clams also provide this ecological service.

Crassostrea virginica. The American oyster is sufficiently important to have stimulated a huge body of research, including a recent book (Kennedy et al. 1996) that synthesizes the present scientific knowledge of oyster biology. Populations of American oysters are grossly depleted throughout the Atlantic estuaries of North America (Rothschild et al 1994, Lenihan \& Peterson 1998), even to the point of functional extinction in most estuaries north of Delaware Bay. Production of sufficient numbers of gametes limits oyster settlement where adult spawning stock biomass is low, such as in lower-salinity waters of the Chesapeake Bay where reconstructed oyster reef habitat fails to receive repeatable settlement. In Southern New England embayments, oyster populations are almost surely recruitment limited as well, given the low size of the oyster populations. Because of the habitat-destroying fishing practice of oyster dredging, which removes the shell reef along with living oysters, habitat for oysters is also limiting (Rothschild et al. 1994). Even the reefs that remain are degraded by reduction of their height, which reduces oyster growth rates and exposes them to catastrophic mortality during hypoxic events (Lenihan \& Peterson 1998). Such hypoxic events are enhanced by eutrophication, meaning that reef habitat degradation and eutrophication interact to help limit oyster abundance and production in deeper areas of stratified estuaries (Lenihan \& Peterson 1998). As juveniles, oysters fall prey to blue crabs and to drilling gas- tropods. Oyster drills can eliminate oyster sets in highsalinity waters and restrict adults to locations higher in the estuary. Two introduced protozoan parasites, Dermo and MSX (Haplosporidium nelsoni), now also kill American oysters before they reach their second birthday, thereby limiting abundance and production of the oysters. Oysters that do find suitable reef habitat and survive the parasites are typically harvested by fishermen. Thus, there are many opportunities for restoration to increase oyster abundance and production that might be used to compensate a spill-induced injury or other loss.

Argopecten irradians. Since the bay scallop is essentially an annual, living for only ca. 18 mo (Belding 1910, Gutsell 1930), abundancetypically fluctuates dramatically from year to year because of the absence of multiple older age classes to stabilize interannual fluctuations. The high interannual variation in recruitment of bay scallops implies that reproductive success acts as a major limitation to bay scallop abundance. If adult spawning stock biomass falls below a threshold level within a hydrographically isolated water basin, bay scallop recruitment will be reduced or fail (Peterson \& Summerson 1992, Peterson et al. 1996). Even at densities higher than this presumed threshold, variation in settlement success probably explains much of the temporal variation in annual cohorts of bay scallops.

Bay scallop larvae must encounter suitable habitat for metamorphosis and settlement, which involves attachment to structures such seagrass (Thayer \& Stuart 1974) or cobbles in some New England estuaries (Belding 1910). Consequently, while settlement habitat almost certainly helps control bay scallop abundance and thereby production, the habitat limitation in New England bays is probably less strong than in the southern lagoons. However, predation on juvenile bay scallops by crabs and demersal fishes is intense enough to exert a strong control on abundance, with seagrass providing a vital service in elevating juvenile scallops up above the seafloor where crabs forage more readily (Pohle et al. 1991). Thus, seagrass restoration would likely benefit bay scallops where recruitment is sufficient.

At all life stages bay scallops are sensitive to physiological stressors like low salinity, sedimentation, and temperature extremes (e.g. Tettelbach et al. 1985). Even as adults, bay scallop densities are reduced by predators such as gulls (Prescott 1990) and rays (Peterson et al. 2001). Fishing is prosecuted on bay scallops throughout their range of high abundance. Because the year class of bay scallops that is fished has already spawned in late summer and is fated to die from senescence before another late summer spawning, fishing pressure is allowed to be extremely high (Peterson 1990). Consequently, the bay scallop possesses not one 
but several factors that act to limit its abundance and production, making it an appealing candidate for restoration. However, its vulnerability to predation and life history characteristics make it less reliable than other bivalve species for mitigating a loss of primarily more robust species.

\section{Effectiveness of bivalve restoration}

Owing to their fishery value and successful use in aquaculture, technologies have been developed to allow artificial propagation of bivalves in hatcheries and subsequent growth in nurseries to a size appropriate for introduction into the field. Thus, stocking of bivalves is feasible, although most reliably and inexpensively for those species whose seed is commercially produced in existing hatcheries, e.g. hard clams, oysters, soft-shell clams, and bay scallops. Surf clams are not commercially raised for aquaculture, but they too should present few challenges given their close taxonomic and ecological similarities to hard clams. Stocking shellfish with seed holds the promise of enhancing abundance and production for species whose settlement is limited by spawning stock biomass or whose abundance is controlled by high mortality during the early post-settlement life stage. Bivalve seeding would not immediately restore the full size and age distribution of the bivalve losses from the oil spill. In addition, successive stocking over several years may be necessary to avoid or counteract any induced densitydependent mortality from predators targeting a rich new food resource. Despite this potential for compensatory mortality to reduce or eliminate the stocking effort, there are good examples of the success of such bivalve seeding (e.g. Beal 1993, Peterson et al. 1995). For shellfish species that have been depleted by overharvest, the benefits of stock enhancement by seeding would be expected to continue for successive generations, especially if the seed areas were protected as spawner sanctuaries. Consequently, this option of seed stocking from hatcheries has many advantages and was included in the 'North Cape' oil spill restoration plan (NOAA et al. 1999, available at www.darp.noaa. gov/neregion/ncape.htm).

Transplantation of larger bivalves into an impacted area could enhance abundance at the impact site, but potentially induces an equivalent loss at the donor area. Nevertheless, there are multiple scenarios by which transplantation, which is readily tolerated by soft-sediment bivalves (e.g. Peterson et al. 1996), could enhance net production. For those species whose spawning stock biomass limits recruitment and ultimate population size, transplantation into a spawner sanctuary could serve to increase population abun- dance and production (e.g. Peterson \& Summerson 1992). To avoid a loss at a donor area, the adults chosen for transplantation could be purchased from the fishery markets. Nevertheless, to enhance net production, the spawner sanctuary would need to be protected from human exploitation and located in an area that is a viable source site (Crowder et al. 2000) from which larvae would be effectively transported to habitat now depleted by exploitation

If relief from recruitment limitation is not the objective, there are alternative scenarios whereby bivalve transplantation may enhance production. For example, if the species suffers depressed individual growth rates at the donor site because of density-dependent competition or otherwise suboptimal growth conditions, then transplantation to the impact area could enhance production by increasing individual growth rates. For the suspension-feeding bivalve molluscs of estuarine and coastal marine soft sediments, however, competition for resources is only rarely an important determinant of individual growth, especially in today's conditions of enhanced eutrophication (Peterson \& Beal 1989).

In considering bivalve restoration options for the 'North Cape' case, plans for dredging in the nearby Providence River involved an unmitigated loss of many hard clams, which could serve as donor individuals for transplantation into the oil-impacted area. However, mitigation for this dredging activity itself is indicated, as the clams in the dredged area are public trust resources. Such a mitigation for dredging impacts on Dungeness crab was pursued in Grays Harbor, Washington, using similar restoration scaling methods involving demographic modeling (Wainwright et al. 1992, Dumbauld et al. 1993). The restoration was to provide structural habitat (shell reef) as juvenile nursery area, resulting in a net gain in crab numbers equivalent to those lost via the dredging.

For several benthic bivalves, evidence is compelling that habitat destruction and modification has reduced their productivity. Shell reef (Luckenbach et al. 1999, Breitburg et al. 2000, O'Beirn et al. 2000) and seagrass (Fonseca et al. 1998) have been restored in many areas to enhance productivity. However, there is no evidence or even indication that surf clams, the species that suffered the vast majority of the injury from the oil spill, are limited by habitat quantity or quality.

For the large majority of species that are targets of commercial fisheries, fishing exploitation occurs at such high levels that their productivity is depressed (Botsford et al. 1997, Pauly et al. 1998). Thus, one very effective restoration action for such species would be to reduce fishing pressure. The detailed models already produced to guide fisheries management provide methods for scaling the reduction in fishing to match the quantitative injury estimate. Furthermore, 
data already maintained on fisheries landings could be used to monitor the effectiveness of the actions taken to reduce fishing pressure such that adaptive corrections could be employed to insure full compensation. However, limitation of bivalve catches as a restoration action would entail a loss of human use and economic losses to the industry. The restoration chosen should not in principle pass on new injuries and costs without applying restoration funds to compensate for these new injuries. The public's use of the resource is compensated by the restoration itself, and the discounting effectively includes the paying of interest for the delay in repayment of services. However, lost profits by private parties are not necessarily compensated. Such compensation of private parties may pose legal barriers, depending on legislation constraining restoration, and would incorporate the need to determine how the injury is distributed across each fishing entity. Documentation of who truly suffered this injury and to what degree would represent a challenging task.

\section{CONCLUSIONS}

Our quantitative calculations of production gains achievable through bivalve restoration are best viewed as hypotheses to be tested. There is substantial uncertainty associated with such projections. In mitigating for environmental injuries, uncertainty is often handled by requiring the scale of mitigation to exceed what is necessary to replace the loss by some mitigation ratio that increases with uncertainty. For example, ratios of 2 to 3 acres of restoration for each acre of salt marsh lost are common (Thayer 1992). Alternatively, monitoring can be done to confirm the effectiveness of any restoration action when combined with any subsequent intervention if necessary to replace lost public trust resources. Choosing this alternative would provide for empirical tests of the accuracy of the modeling done to scale the restoration projects and thus lead to improved understanding of the basic demographic processes and reducing uncertainty in future applications.

We developed our quantitative scaling of bivalve restoration purely on the basis of production. We justify that choice on grounds that it represents one important ecosystem process that correlates well with the ecosystem services of water filtration and biogeochemical processing of materials (Kremer \& Nixon 1978, Newell 1988). Nevertheless, compensatory restoration might benefit from more extensive identification and quantification of the full range of ecosystem services provided by bivalves (and other groups) so that restoration projects could be designed to replace the actual ecosystem functions that were damaged or lost. Perhaps the greatest failure of an approach based on production alone is the absence of a constraint on the size class(es) in which the replacement production is to occur. Small bivalves have great value as prey for higher trophic levels, so if restoration were to involve only larger individuals, then the function of transfer of energy up the food chain may not be adequately restored. In addition, the implicit treatment of all suspension-feeding bivalves as functionally equivalent can be challenged. Here, surf clams occupy an entirely different habitat, the coastal ocean, than oysters, softshell clams, and bay scallops, which live in the protected estuarine waters. Thus, their ecosystem contributions are made to different systems, where they may not be of equal value or importance. Furthermore, assumptions of equivalence in value of ecosystem services across species of bivalves can lead to decisions to use but one species to restore losses of many. In the 'North Cape' oil spill example used here, this is not an issue because the vast majority of the injury occurred to a single species. However, future application of this approach to situations where several species contributed heavily to the injury raises concern over maintaining biodiversity within the ecosystem. Sustaining biodiversity is an important goal of environmental conservation (Wilson \& Peters 1988). Current theory and empirical data tend to support the view that redundancy of species within functional groups provides greater stability of functions like production under varying environmental conditions (Naeem et al. 1994). Embracing that principle in restoration of ecosystem services would imply more diverse efforts spread among several species rather than the choice of a single most cost-efficient, expedient, or reliable species.

Acknowledgements. Support for this work was provided by the National Oceanographic and Atmospheric Administration, Damage Assessment Center (NOAA DAC), Silver Spring, MD. We thank C. A. Manen for her guidance and all the 'North Cape' oil spill trustees for thoughtful contributions. M. Donlan provided administrative assistance. Comments from B. Beal, H. Bloom, H. Gempp, C. Judy, J. Kraeuter, R. Krauss, S. Malinowski, R. Mann, C. McKenzie, R. Rheault, J. Weinberg, and J. Wesson are gratefully acknowledged.

\section{LITERATURE CITED}

Arnold WS (1984) The effects of prey size, predator size, and sediment composition on the rate of predation of the blue crab, Callinectes sapidus Rathbun, on the hard clam, Mercenaria mercenaria (Linne). J Exp Mar Biol Ecol 80:207-219

Beal BP (1983) Predation of juveniles of the hard clam Mercenaria mercenaria (Linne) by the snapping shrimp Alpheus heterochaelis Say and Alpheus normanni Kingsley. J Shellfish Res 3:1-9

Beal BP (1993) Effects of initial clam size and type of protective mesh netting on survival and growth of hatcheryraised individuals of Mya arenaria in eastern Maine. J Shellfish Res 12:138-139 
Belding DL (1910) A report upon the scallop fishery of Massachusetts. Commonwealth of Massachusetts, Boston

Botsford LW, JC Castilla, CH Peterson (1997) The management of fisheries and marine ecosystems. Science 277:509-515

Breitburg, D, Coen LD, Luckenbach MW, Mann R, Posey M, Wesson JA (2000) Oyster reef restoration: convergence of harvest and conservation strategies. J Shellfish Res 19: 371-377

Castagna M, Kraeuter JN (1985) Mercenaria culture using stone aggregate for predator protection. Proc Natl Shellfish Assoc 67:1-6

Cloern JE (1982) Does the benthos control phytoplankton biomass in south San Francisco Bay? Mar Ecol Prog Ser 9: 191-202

Crowder LC, Lyman SJ, Figuiera WF, Priddy J (2000) Sourcesink population dynamics and the problem of siting marine reserves. Bull Mar Sci 66:799-820.

Dumbauld BR, Armstrong DA, McDonald TL (1993) Use of oyster shell to enhance intertidal habitat and mitigate loss of Dungeness crab (Cancer magister) caused by dredging. Can J Fish Aquat Sci 50:381-390

Fay CW, Neves RJ, Pardue GB (1983) Species profiles: life histories and environmental requirements of coastal fishes and invertebrates (Mid-Atlantic). Surf clam, Report FWS/ OBS-82/11.13, US Fish Wildl Serv, Washington, DC

Fonseca MS, Meyer DL, Hall MO (1996) Development of planted seagrass beds in Tampa Bay, Florida, USA. II. Faunal components. Mar Ecol Prog Ser 132:141-156

Fonseca MS, Kenworthy WJ, Thayer GW (1998) Guidelines for the conservation and restoration of seagrasses in the United States and adjacent waters. NOAA Coastal Ocean Program Decision Analysis Series No 12. NOAA Coastal Ocean Office, Silver Spring, MD

Franz DR (1976) Distribution and abundance of inshore populations of the surf clam Spisula solidissima. Am Soc Limnol Oceanogr Spec Symp 2:404-413

French DP, Rines H (1998) Estimation of losses in the salt ponds resulting from water column and sediment acute toxicity from the North Cape oil spill. NOAA Damage Assessment Center, Silver Spring, MD (part of case administrative record, available at http://www.darp.noaa. gov/neregion/ncape.htm)

French DP, Rines H, Boothroyd J, Galagan C and 9 others (1991) Habitat inventory/resource mapping for Narragansett Bay and associated coastline. Final Report, Narragansett Bay Project, New England Interstate Water Pollution Control Commission, US Environmental Protection Agency, Boston

French DP, Reed M, Jayko K, Feng S and 16 others (1996) The CERCLA type A natural resource damage assessment model for coastal and marine environments (NRDAM/ CME), technical documentation, Vol. I-V. Final Report, Contract No. 14-0001-91-C-11, Office of Environmental Policy and Compliance, US Department of the Interior, Washington, DC

French McCay DP (2002) Development and application of an oil toxicity and exposure model, OilToxEx. Environ Toxicol Chem 21:2080-2094

French McCay DP (2003) Development and application of damage assessment modeling: Example assessment for the North Cape oil spill. Mar Pollut Bull 47:341-359

Gibson MR (1997) Estimated strandings of surf clams and other species following the North Cape oil spill in Block Island Sound. Division of Fish and Wildlife, Rhode Island Dept of Environmental Management, Wickford (part of case administrative record, available at http://www.darp. noaa.gov/neregion/ncape.htm)
Grosselin LA, Qian PY (1997) Juvenile mortality in benthic marine invertebrates. Mar Ecol Prog Ser 146:265-282

Gutsell JS (1930) Natural history of the bay scallop. Bull US Bur Fish 46:569-632

Hancock DA (1973) The relationship between stock and recruitment in exploited invertebrates. Rapp p-v Reun Cons Int Eplor Mer 164:113-131

Hinga KR (1997) Concentrations over time of North Cape oil in water and sediments in Rhode Island's south shore ponds. Report by University of Rhode Island, Narragansett, to NOAA Damage Assessment Center, Silver Spring, (part of case administrative record, available at http://www.darp.noaa.gov/neregion/ncape.htm)

Hunt JH, Ambrose WG Jr, Peterson CH (1987) Effects of the gastropod, Ilynassa obsoleta (Say), and the bivalve, Mercenaria mercenaria (L.), on larval settlement and juvenile recruitment of infauna. J Exp Mar Biol Ecol 108:229-240

Jackson JBC, Kirby MX, Berger WH, Bjorndal KA and 15 others (2001) Historical overfishing and the recent collapse of coastal ecosystems. Science 293:629-638

Jordan WR, Gilpin ME, Aber JD (1987) Restoration ecology. Cambridge University Press, Cambridge

Kennedy VS, Newell RIE, Eble AF (1996) The eastern oyster. Crassostrea virginica. Maryland Sea Grant, College Park

Kraeuter JN (2001) Predation on hard clams. In: Kraeuter JN, Castaga M (eds) Biology of the hard clam. Pergamon Press, Oxford

Kraeuter JN, Castagna M (eds) (2001) Biology of the hard clam. Pergamon Press, Oxford

Kremer JN, Nixon SW (1978) A coastal marine ecosystem: simulation and analysis. Springer-Verlag, Berlin

Lenihan HS, Peterson CH (1998) How habitat degradation through fishery disturbance enhances impacts of hypoxia on oyster reefs. Ecol Appl 8:128-140

Luckenbach MW, Mann R, Wesson JA (eds) (1999) Oyster reef habitat restoration. A synopsis and synthesis of approaches. Virginia Institute of Marine Science Press, Gloucester Point

MacIsaac HJ, Johannsson OE, Ye J, Sprules WG, Leach JH, McCorquodale JA, Gingorovich IA (1999) Filtering impacts of an introduced bivalve (Dreissena polymorpha) in a shallow lake: application of a hydrodynamic model. Ecosystems 2:338-350

MacKenzie CL Jr, Radosh DJ, Reid R (1985) Densities, growth, and mortalities of juveniles of the surf clam (Spisula solidissima) (Dillwyn) in the New York Bight. J Shellfish Res 5:81-84

Naeem S, Thompson LJ, Lawler SP, Lawton JH, Woodfin RM (1994) Declining biodiversity can alter the performance of ecosystems. Nature 368:734-737

Newell RIE (1988) Ecological changes in the Chesapeake Bay: are they the result of overharvesting the American oyster, Crassostrea virginica? In: Lynch MP, Krome EC (eds) Understanding the estuary: advances in Chesapeake Bay research. Publication No. 129 CBP/TRS 24/88, Chesapeake Bay Research Consortium, Gloucester Point, VA, p 536-546

Newell RIE, Cornwell JC, Owens MS (2002) Influence of simulated bivalve biodeposition and microphytobenthos on sediment nitrogen dynamics: a laboratory study. Limnol Oceanogr 47:1367-1379

NMFS (National Marine Fisheries Service) (1995) Status of fishery resources off the northeastern United States for 1994. NOAA Tech Mem NMFS-NE-108

Nichols FH, Thompson JK, Schemel LE (1990) Remarkable invasion of San Francisco Bay (California, USA) by the Asian clam Potamocorbula amurensis. 2. Displacement of a former community. Mar Ecol Prog Ser 66:95-101 
NOAA (National Oceanic and Atmospheric Administration) (1997) Natural resource damage assessment guidance document: scaling compensatory restoration actions (Oil Pollution Act of 1990). NOAA Damage Assessment Center, Silver Spring, MD

O'Beirn FX, Luckenbach MW, Nestlerode JA, Coates GM (2000) Toward design criteria in constructed oyster reefs: oyster recruitment as a function of substrate type and tidal height. J Shellfish Res 19:387-395

Olsen SB (1970) Some aspects of the ecology of Spisula solidissima solidissima (Dillwyn). MSc thesis, University of Rhode Island, Kingston

Orth RJ, Moore KA (1983) Chesapeake Bay — an unprecedented decline in submerged aquatic vegetation. Science 222:51-53

Paine RT (1980) Food webs: linkage, interaction strength and community infrastructure. J Anim Ecol 49:667-685

Pauly D, Cristensen V, Dalsgaard J, Froee R, Torres F Jr (1998) Fishing down marine food webs. Science 279:860-863

Peterson CH (1982) Clam predation by whelks (Busycon spp.): experimental tests of the importance of prey size, prey density, and seagrass cover. Mar Biol 66:159-170

Peterson CH (1986a) Quantitative allometry of gamete production by Mercenaria mercenaria into old age. Mar Ecol Prog Ser 29:93-97

Peterson CH (1986b) Enhancement of Mercenaria mercenaria densities in seagrass beds: Is pattern fixed during settlement season or altered by subsequent differential survival? Limnol Oceanogr 31:200-205

Peterson CH (1990) On the role of ecological experimentation in resource management: managing fisheries through mechanistic understanding of predator feeding behavior. In: Hughes RH (ed) Behavioural mechanisms of food selection. Springer-Verlag, Berlin, p 821-846

Peterson CH (2002) Recruitment overfishing in a bivalve mollusc fishery: hard clams (Mercenaria mercenaria) in North Carolina. Can J Fish Aquat Sci 59:96-104

Peterson CH, Beal BP (1989) Bivalve growth and higher order interactions: importance of density, site, and time. Ecology 70:1390-1404

Peterson CH, Summerson HC (1992) Basin-scale coherence of population dynamics of an exploited marine invertebrate, the bay scallop: implications of recruitment limitation. Mar Ecol Prog Ser 90:257-272

Peterson CH, Summerson HC, Duncan PB (1984) The influence of seagrass cover on population structure and individual growth rate of a suspension-feeding bivalve, Mercenaria mercenaria. J Mar Res 42:123-138

Peterson CH, Summerson HC, Huber J (1995) Replenishment of hard clam stocks using hatchery seed: combined importance of bottom type, seed size, planting season, and density. J Shellfish Res 14:293-300

Peterson CH, Summerson HC, Luettich RA Jr (1996) Response of bay scallops to spawner transplants: a test of recruitment limitation. Mar Ecol Prog Ser 132:93-107

Editorial responsibility: Ronald Kneib,

Sapelo Island, Georgia, USA
Peterson CH, Fodrie FJ, Summerson HC, Powers SP (2001) Site-specific and density-dependent extinction of prey by schooling rays: generation of a population sink in top-quality habitat for bay scallops. Oecologia 129: 349-356

Pohle DG, Bricelj VM, Garcia-Esquivel Z (1991) The eelgrass canopy: an above-ground refuge from benthic predators for juvenile bay scallops Argopecten irradians. Mar Ecol Prog Ser 74:47-59

Prescott RC (1990) Sources of predatory mortality in the bay scallop Argopecten irradians (Lamarck): interactions with seagrass and epibiotic coverage. J Exp Mar Biol Ecol 144: 63-83

Rice MA, Hickox C, Zehra I (1989) Effects of intensive fishing effort on the population structure of quahogs, Mercenaria mercenaria (Linnaeus 1758), in Narragansett Bay. J Shellfish Res 8:345-354

Ricker WE (1975) Computation and interpretation of biological statistics of fish populations. Bull Fish Res Board Can 191:1-382

Rothschild BJ, Ault JS, Goulletquer P, Heral M (1994) Decline of the Chesapeake Bay oyster population: a century of habitat destruction and overfishing. Mar Ecol Prog Ser 111:29-39

Tettelbach ST, Auster PJ, Rhodes EW, Widman JC (1985) A mass mortality of the northern bay scallop, Argopecten irradians irradians, following a severe spring rainstorm. Veliger 27:381-385

Thayer GW (ed) (1992) Restoring the Nation's marine environment. Maryland Sea Grant College Program, College Park

Thayer GW, Stuart HH (1974) The scallop makes its bed of eelgrass. US Natl Mar Fish Serv Mar Fish Rev 36:27-39

Wainwright TC, Armstrong DA, Dinnel PA, Orensanz JM, McGraw KA (1992) Predicting effects of dredging on a crab population: an equivalent adult approach. Fish Bull 90:171-182

Watzin MC (1983) The effects of meiofauna on settling macrofauna: meiofauna may structure macrofaunal communities. Oecologia 59:163-166

Weinberg JR, Hesler TE (1996) Growth of the Atlantic surf clam, Spisula solidissima, from Georges Banks to the Delmarva Peninsula, USA. Mar Biol 126:663-674

Weissberger EJ (1998) The effects of predation on the recruitment of the surf clam Spisula solidissima. PhD thesis, Rutgers University, New Brunswick, NJ

Wilson EO, Peters FM (eds) (1988) Biodiversity. National Academy Press, Washington, DC

Wilson FS (1990) Temporal and spatial patterns of settlement: a field study of molluscs in Bogue Sound, North Carolina. J Exp Mar Biol Ecol 139:201-220

Zedler JB (1995) Salt marsh restoration: lessons from California. In: Cairns J (ed) Rehabilitating damaged ecosystems. Lewis Publishers, Boca Raton, FL, p 75-95

Submitted: June 13, 2003; Accepted: November 24, 2003

Proofs received from author(s): December 9, 2003 